\title{
Benefits of Near-Peer Tutoring in Small Group Discussions: A Pilot Study
}

\author{
Shazia Muazam ${ }^{1}$, Farzana Majeed ${ }^{2}$, Saima Mumtaz Khattak ${ }^{3}$ \\ ${ }^{1}$ Associate Professor, Department of Anatomy, HBS Medical \& Dental College, Islamabad Pakistan \\ ${ }^{2}$ Associate Professor, Department of Physiology, HBS Medical \& Dental College, Islamabad Pakistan \\ ${ }^{3}$ Assistant Professor, Department of Anatomy, Federal Medical \& Dental College, Islamabad Pakistan
}

\begin{abstract}
A B S T R ACT
Background: A year senior medical students can prove to be a useful teaching resource with added benefits for the tutors. The objective of this study was to explore the perceptions of near-peer tutors after facilitating small group discussions while delivering an integrated curriculum in preclinical years.

Material and Methods: This qualitative exploratory pilot study was conducted in Rawal Institute of Health Sciences Islamabad, Pakistan from July 2017 to November 2017. Students of First year MBBS class ( $n=100)$, were divided into six small groups. Seven Second year MBBS students who had secured more than $60 \%$ marks throughout year one assessments and in Professional examination were selected as Near-Peer tutors after informed verbal consent. In the first discussion, three groups were taught by three tutors and three by junior faculty. In the second discussion, the groups were swapped and exposed to the same strategy as above, with new learning objectives, but the remaining three tutors now took batches. One tutor acted as a substitute. Qualitative data was collected after interviewing the tutors individually and responses were audio recorded. The collected data, both notes and audio recordings of the interviews, was transcribed into text to generate codes, theme and sub themes.

Results: Transcription of data revealed that the tutors enjoyed teaching and were of the opinion that Near-Peer tutoring is more effective in small groups, for both tutors and the learners. The tutors felt a boost in self-confidence and improvement in communication skills, after facilitating a small group. Tutoring also helped in developing their higher order cognitive thinking, learning skills and time management.

Conclusions: Near-Peer tutoring helped the tutors develop learning and communications skills while facilitating small group sessions, thus helping them in their future medical roles.

Key words: Integrated curriculum, Near-Peer tutoring, Peer Assisted Learning, Small group discussions.

Authors' Contribution:

${ }^{1}$ Conception; Literature research; manuscript

design and drafting; ${ }^{2,3}$ Critical analysis and

manuscript review; Data analysis; Manuscript

Editing.

Correspondence: Article info:

Shazia Muazam

Email:shaziamuazam@gmail.com

Received: July 30, 2020

Accepted: January 15, 2021
\end{abstract}

Cite this article. Muazam S, Majeed F, Khattak SM. Benefits of Near-Peer Tutoring in Small Group Discussions: A Pilot Study. J Islamabad Med Dental Coll. 2021; 10(1): 23-30. Doi:

Funding Source: Nil 10.35787/jimdc.v10i1.577

\section{Introduction}

Peer Assisted Learning (PAL) is an instructional strategy where "learning is through active help of peer group members". Peer are the people belonging to the same social grouping. ${ }^{1}$ Near-Peer 
Assisted Learning (NPAL) is a variant of PAL in which the tutor is at least one year senior to the learners in context of medical training. ${ }^{2}$ NPAL has been applied to deliver lectures, tutorials, laboratory practical and clinical skills formally worldwide. ${ }^{3,4}$ PAL/NPAL leads to better cognitive congruence between the participants. ${ }^{5}$ The role of tutors is found to be equivalent to clinicians and nurses in clinical skills training. ${ }^{6}$ Peer tutoring nurtures development of metacognitive, communication and professionalism skills among the peer tutors. ${ }^{7}$ They relieve the burden of teaching from the faculty thereby, enabling them to take part in productive activities. ${ }^{8}$ In Pakistan, few PAL studies led to the conclusion that PAL is as effective as facilitator assisted learning. ${ }^{9,10}$ Another national quantitative study showed that horizontal PAL can actually replace expert assisted learning in teaching clinical skills to the undergraduates. ${ }^{11}$

Small group discussions (SGDs) are a commonly used teaching strategy in delivering concepts in an integrated curriculum, worldwide. ${ }^{12}$ Rapid turnover and paucity of junior faculty involved in SGDs, affects the quality of delivery. Clinical experts due to busy hospital routine cannot justify their roles as teachers in preclinical integrated modules. ${ }^{13}$

Scant literature is available on the use of Near-Peer tutors in SGDs, along with faculty, to deliver correlational concepts, in an integrated curriculum in preclinical years. Our study aims to generate qualitative data on the perceptions of Near-Peer tutors about NPAL and, their gains after tutoring small groups to deliver complex integrated concepts.

\section{Material and Methods}

This qualitative exploratory pilot study, based on theoretical framework of grounded theory, was conducted in Rawal Institute of Health Sciences, Islamabad, Pakistan, from July 2017 to November 2017. After approval from the Ethical Review
Committee of Rawal Institute of Health Sciences, the first year MBBS students were included by convenience sampling for NPAL intervention. Seven students of second year MBBS were selected as Near-Peer tutors by purposive sampling, with the inclusion criteria set as the students who secured more than $60 \%$ marks throughout year one assessments and in the professional examination. Undergraduate students of Dentistry and other Allied Sciences, and faculty members of Basic and Clinical sciences were excluded as Near-Peer tutors.

The curriculum in first two years of MBBS is delivered in three Blocks each, where the Basic Sciences subjects are horizontally integrated with each other, and vertically with Clinical Sciences. Block 2, concerned with integration of upper limb Anatomy, nerve Physiology, Biochemical and Clinical aspects, was selected for using NPAL in small groups.

Verbal consent was taken from the tutors after explaining the study and assuring them of maintaining their confidentiality by using pseudonyms in the data analysis. It was clarified, that out of seven tutors only six would participate in active teaching, while the seventh would act as a substitute, in case any tutor could not take the class. One of them volunteered, himself, for acting as a substitute. The tutors were given a training session of two hours by the Principal Investigator (PI) on different teaching and learning strategies, use of learning resources, facilitation of small groups and giving feedback. At the end of the training session, the tutors were handed learning objectives of both SGDs, so as to prepare themselves.

The First-year class was divided into six small groups/batches, A-F with 12 to 15 students in each batch. Batches A, B and C first attended an SGD session with the junior faculty while Batches $D, E$ and $F$ attended the session with three NPAL tutors. The session lasted for two hours. Both the NPAL assisted and non-assisted groups had similar learning 
objectives regarding four nerves of upper limb, their injuries and correlation of symptoms with the site of lesion. In second SGD, the batches were flipped and exposed to the same strategy as above, with new learning objectives regarding three new nerves. Those taught by junior faculty in first session were taught by the remaining three Near-Peer tutors, while the rest of three small groups were taught by junior faculty thus, exposing the whole First year to Near-Peer tutors.

Qualitative data was collected from all six tutors by holding individual interviews conducted by the PI, who holds an MPhil degree and is currently enrolled as an MHPE (Masters in Health Professions Education) student. The interviews were held and audio recorded the next day after the second SGD in the PI office. An interview guide, prepared after consultation with a colleague and a medical educationist, in advance, guided the interviewer in the process. The interview started with open ended questions, proceeded forward with follow up and probe questions to make the tutors elaborate their responses. Notes were taken. Each interview lasted for fifty minutes, on an average.

The collected data, both notes and audio recordings of the interviews, was transcribed by PI into text. The text was read multiple times to draw deeper meaning. Being a pilot study, the data was small, so it was analyzed manually. The text was divided into segments of information. Different colored highlighters were used to mark familiar texts to generate codes. Same codes were overlapped or discarded, thus reducing 30 codes into four themes depending on their broad meaning and seven subthemes were extracted from themes. Few amendments were made after review of raw data by a non-medical peer. To eliminate researcher bias, raw data was sent to a medical educationist who validated the transcriptions, codes, themes and subthemes. Member checking was done by sending the text data to the tutors.

\section{Results}

Analysis of data resulted in emergence of four themes underlying four categories. Seven subthemes were extracted from the four themes (Table I).

\section{Discussion}

The tutors involved in our study enjoyed the experience of teaching in small groups and found it beneficial for themselves and for the learners. The first theme highlighted a new aspect where the tutors developed an insight of pursuing teaching as a profession. Our Near tutors, initially clinically oriented, started considering teaching as a profession, as they were attracted by the satisfaction which one attains after delivering a content. The second theme developed as the tutors felt that NPAL is beneficial for the learners. Nearpeer tutors can understand the hurdles in learning as both learners and tutors are at the same mental status, therefore tutors try to overcome them. They can readily integrate new learning experiences and techniques into the curriculum.

Different researchers have proved that pairing junior and senior undergraduate students enhances psychological support and helps in improving professional and personal development in both. ${ }^{14}$ Our tutors guided the learners about different learning resources and time management. Peer tutors have been shown to create an atmosphere that allows learners to exchange ideas in a stressfree manner. ${ }^{15}$ Theme three of our study exhibited that during small group preparation, tutors developed deeper understanding of the subject matter thus encouraging them to deliver confidently. Revisit of previously learnt topics helped in strengthening their own concepts which would prove beneficial in their future medical career. 


\begin{tabular}{|c|c|c|}
\hline \multicolumn{3}{|c|}{ Table I: Categories, themes and few verbatim } \\
\hline CATEGORIES & \multicolumn{2}{|l|}{ THEMES/ SUBTHEMES } \\
\hline \multirow{5}{*}{$\begin{array}{l}\text { 1. NPAL as a } \\
\text { teaching } \\
\text { experience }\end{array}$} & \multicolumn{2}{|l|}{ THEME 1: CONCEPT ABOUT TEACHING } \\
\hline & \multicolumn{2}{|l|}{ SUBTHEME A: TEACHING IS A SKILL } \\
\hline & $\begin{array}{l}\text { All six tutors affirmed that their concept about } \\
\text { teaching changed altogether. They had become } \\
\text { aware of the efforts required for conducting a } \\
\text { teaching session and how well prepared a teacher } \\
\text { had to be to answer the queries of the learner. } \\
\text { Three of the tutors, being overwhelmed by the } \\
\text { experience, thought to pursue it as a career }\end{array}$ & $\begin{array}{l}\text { "Teaching is a technique and a skill." } \\
\text { "The experience was a bit of adventure for } \\
\text { me" } \\
\text { "Teaching was most attractive feature of } \\
\text { this strategy" } \\
\text { "I never felt as if I can think about teaching } \\
\text { as a profession, but after these sessions I } \\
\text { have started thinking about it." }\end{array}$ \\
\hline & \multicolumn{2}{|l|}{ SUBTHEME B: IMPROVED COMMUNICATION SKILLS } \\
\hline & $\begin{array}{l}\text { The teaching experience gave them the confidence } \\
\text { to speak in public, thus enhanced their } \\
\text { communication skills. They particularly enjoyed } \\
\text { when they were able to answer the questions asked } \\
\text { by the learners. }\end{array}$ & $\begin{array}{l}\text { "I gained confidence; my way of talking } \\
\text { improved." } \\
\text { "I was unaware of my confidence until now } \\
\text { and felt proud to be able to answer the } \\
\text { queries asked by learners." } \\
\text { "...communication skills are so much } \\
\text { important I had no idea." } \\
\text { "I have learned that for one to be a good } \\
\text { teacher one should be a good listener and } \\
\text { have patience." }\end{array}$ \\
\hline \multirow[b]{2}{*}{$\begin{array}{l}\text { 2. NPAL as a } \\
\text { learning strategy } \\
\text { for learners }\end{array}$} & \multicolumn{2}{|l|}{ THEME 2: BENEFICIAL FOR LEARNERS } \\
\hline & $\begin{array}{l}\text { The tutors were of opinion that NPAL is an effective } \\
\text { teaching strategy regarding tutees as first year } \\
\text { students mostly require guidelines about the course } \\
\text { content and time management, which can be best } \\
\text { provided by the ones who have gone through the } \\
\text { same situation only a year ago. Near tutors are also } \\
\text { aware of complex concepts which the learners } \\
\text { usually are unable to understand, so their teaching } \\
\text { is targeted unlike faculty. } \\
\text { NPAL stimulated the learners as they seemed to be } \\
\text { more vocal and interested even at the end of two } \\
\text { hours session. }\end{array}$ & $\begin{array}{l}\text { "I think it is a good learning strategy for } \\
\text { tutees because as a tutor I guided them } \\
\text { about how to use various learning } \\
\text { resources, which topics to focus on; guided } \\
\text { them on time management while } \\
\text { preparing for exam as well as in attempting } \\
\text { paper." } \\
\text { "Even the students who initially seemed to } \\
\text { be uninterested, asked questions at the } \\
\text { end thus showing their interest." } \\
\text { "If this has been practiced with us, we } \\
\text { would have performed better than this } \\
\text { time." }\end{array}$ \\
\hline
\end{tabular}




\begin{tabular}{|c|c|c|}
\hline \multirow{5}{*}{$\begin{array}{l}\text { 3. NPAL as a } \\
\text { learning strategy } \\
\text { for tutors }\end{array}$} & \multicolumn{2}{|l|}{ THEME 3: BENEFICIAL FOR TUTORS } \\
\hline & \multicolumn{2}{|c|}{ SUBTHEME A: DEVELOPMENT OF ABILITY TO DO A COMPREHENSIVE LITERATURE SEARCH } \\
\hline & $\begin{array}{l}\text { Regarding their own learning experience while } \\
\text { delivering NPAL sessions, all the } 6 \text { tutors felt it to be } \\
\text { beneficial for them. While preparing for the sessions } \\
\text { they did not restrict themselves to course books but } \\
\text { used reference books and internet. This enhanced } \\
\text { their knowledge which they felt would be very } \\
\text { beneficial in their clinical years. }\end{array}$ & $\begin{array}{l}\text { "I got lots of information regarding content } \\
\text { while searching for the sessions" } \\
\text { "... because of thorough study while } \\
\text { preparing for lectures I can now relate } \\
\text { many clinical symptoms; the symptoms } \\
\text { were not explained by the teachers to us } \\
\text { but as I came to know them, I explained it } \\
\text { to the class." } \\
\text { "The questions put forward by the learners } \\
\text { made me search once again. I consulted } \\
\text { internet for more images to clarify my own } \\
\text { concepts; this was a new experience as I } \\
\text { had never done that before when I was in } \\
1^{\text {st }} \text { year; I only read my course books" }\end{array}$ \\
\hline & \multicolumn{2}{|c|}{ SUBTHEME B: DEVELOPMENT OF HIGHER ORDER COGNITIVE THINKING } \\
\hline & $\begin{array}{l}\text { They also felt that by consulting different learning } \\
\text { resources they could now comprehend the clinical } \\
\text { scenarios with much ease which would help in their } \\
\text { exams while attempting MCQ's. } \\
\text { They were of the opinion that their concept building } \\
\text { was improved while preparing for the sessions }\end{array}$ & $\begin{array}{l}\text { "After this when I sat for my USMLE } \\
\text { preparation it took me less time to solve } \\
\text { the MCQ's of nerve injuries than I used to } \\
\text { do before." } \\
\text { "I feel like by being a tutor our approach } \\
\text { will definitely be better than our colleagues } \\
\text { in the clinics." }\end{array}$ \\
\hline & \multicolumn{2}{|l|}{ SUBTHEME C: EFFECTIVE TIME MANAGEMENT } \\
\hline & $\begin{array}{l}\text { Two of the tutors were very positive of developing } \\
\text { effective management of their time while preparing } \\
\text { for their sessions. } \\
\text { They realized that by doing clinically oriented study } \\
\text { their Basic concepts were clarified and now could } \\
\text { correlate Basics and Clinical with more ease and in } \\
\text { less time, which would help them in future. }\end{array}$ & $\begin{array}{l}\text { "While preparing for sessions I fixed } 15 \text { min } \\
\text { each day out of one hour of my studies for } \\
\text { searching and preparing for NPAL session } \\
\text { thus managed time effectively." } \\
\text { "Studying the signs and symptoms of nerve } \\
\text { injuries before studying gross anatomy } \\
\text { saved me time to understand the boring } \\
\text { courses of nerves; the images of shapes of } \\
\text { arm and hand due to nerve lesions } \\
\text { enforced the anatomical concepts in less } \\
\text { time" }\end{array}$ \\
\hline
\end{tabular}




\begin{tabular}{|c|c|c|}
\hline \multirow{5}{*}{$\begin{array}{l}\text { 4. NPAL teaching } \\
\text { in small groups }\end{array}$} & \multicolumn{2}{|l|}{ THEME 4: BENEFICIAL IN SMALL GROUPS } \\
\hline & \multicolumn{2}{|l|}{ SUBTHEME A: EASILY MANAGEABLE } \\
\hline & $\begin{array}{l}\text { All six of them found it better to conduct NPAL in a } \\
\text { small group as it was easy to handle the learners. } \\
\text { Maintenance of discipline was easy in small groups. } \\
\text { Delivering NPAL lectures would have been difficult } \\
\text { for the tutors and might have not been productive } \\
\text { for learners. } \\
\text { One tutor appreciated the seating arrangements in } \\
\text { small groups which could be readjusted according to } \\
\text { needs. }\end{array}$ & $\begin{array}{l}\text { "Smaller the group lesser the deviation, } \\
\text { more the attention." } \\
\text { "Even I would suggest to reduce the } \\
\text { number of tutees to } 10 \text { for more } \\
\text { effectiveness of NPAL session." } \\
\text { "I found myself more powerful and } \\
\text { confident while managing a small group. } \\
\text { The students also behaved very well in } \\
\text { small group. I didn't feel the need to } \\
\text { discipline them." } \\
\text { "NPAL lecture format will be tiring and } \\
\text { scary at the same time for tutor; it would } \\
\text { be difficult to control a class of } 100 \\
\text { students as they have some respect for the } \\
\text { teacher but may not have such feeling for } \\
\text { tutors" }\end{array}$ \\
\hline & \multicolumn{2}{|c|}{ SUBTHEME B: EASY AND PRODUCTIVE TRANSFER OF KNOWLEDGE } \\
\hline & $\begin{array}{l}\text { The tutors found it easy to explain the difficult } \\
\text { concepts and to answer learners' questions. } \\
\text { Transfer of knowledge was easy due to one-to-one } \\
\text { interaction. }\end{array}$ & $\begin{array}{l}\text { "Giving a MCQ test at the end of small } \\
\text { group session is a quick way to assess } \\
\text { knowledge gain by NPA tutoring ......even a } \\
\text { quiz at the end will be very helpful. Such } \\
\text { formative assessments can be easily } \\
\text { applied in small groups and a constructive } \\
\text { feedback can be given appropriately." } \\
\text { "I thought that it was difficult to make } \\
\text { them understand different hand } \\
\text { appearances in nerve injuries and their } \\
\text { correlation with site of lesion but small } \\
\text { group made me ask all the students } \\
\text { individually if they understood or not " }\end{array}$ \\
\hline
\end{tabular}


It is a known fact that teaching others result in a $90 \%$ retention of material. ${ }^{16}$ Alveraz and Shultz also observed that tutoring in Anatomy made the tutors learn better use of available resources. ${ }^{17}$ Peer tutoring increases tutors' confidence in their own performance assessments. ${ }^{18}$ Tutoring experience provides not only the opportunity to refresh tutor's subject knowledge but also develops employability skills such as leadership, facilitation, projectmanagement, communication and inter-personal skills. ${ }^{19}$ Our tutors felt more confident in communication and their self-efficacy was enhanced after answering learners'. It may be because of the fact that the tutors were one year senior to the learners but even same level peers had been shown to develop competency skills. ${ }^{20}$ Studies on peer assisted tutoring has been documented to develop the skills, attitudes and practices of a competent teacher, ${ }^{20,21}$ though no studies are found to see the long-term effect of such interventions on tutors.

A noticeable theme detected in our study is that all tutors found 'small groups' ideal for delivering complex concepts integration by peer-assisted learning. From facilitation point of view, our tutors felt confident when they had to manage small number of students and it was easy to maintain discipline. Though large group PAL strategy is more effective for the tutor as it gives them the ability to prepare and present in front of a large audience but lack of feedback and fewer interactions due to less developed teaching skills are the drawbacks. ${ }^{22}$

Our study was limited in scope, as being a pilot study, it was restricted to only two SGDs due to conflict in scheduling of Near-Peer tutors and learners' classes. Thus, the number of tutors was restricted. It is recommended to conduct such learning strategy in a whole Block with a number of different tutors having different academic ranking, to see the effect of such an intervention on tutors. We would also recommend to follow-up the tutors to see the long-lasting effects of tutoring.

\section{Conclusion}

Students when used as Near-Peer tutors in small group discussions in preclinical years of medical school develop strong learning and communication skills which will be beneficial for them in their future roles as competent physicians. They can act as an adjunct resource with faculty, in delivering an integrated curriculum in small groups.

\section{References}

1. Olaussen A, Reddy P, Irvine S, Williams B. Peerassisted learning: time for nomenclature clarification. Med Educ Online. 2016; 21(1): 30974. Doi: 10.3402/meo.v21.30974.

2. de Menezes S, Premnath D. Near-peer education: a novel teaching program. Int J Med educ. 2016; 7: 160-67. Doi: 10.5116/ijme.5738.3c28.

3. Rosenberg CJ, Nanos KN, Newcomer KL. The "nearpeer" approach to teaching musculoskeletal physical examination skills benefits residents and medical students. PM\&R. 2017; 9(3): 251-7. Doi: 10.1016/j.pmrj.2016.06.004.

4. de los Ángeles Cambrón-Carmona M, de Lara CNT, Caracuel IR, Cepas FL, González RG, Lozano SZ, et al. Near-peer Teaching in Histology Laboratory. Int J Med Stud. 2016; 4(1): 14-8.

5. Loda $T$, Erschens R, Loenneker $H$, Keifenheim KE, Nikendei C, Junne $F$, et al. Cognitive and social congruence in peer-assisted learning-A scoping review. PloS one. 2019; 14(9): e0222224. Doi: 10.1371/journal.pone.0222224.

6. Abay EŞ, Turan S, Odabaşı O, Elçin M. Who is the preferred tutor in clinical skills training: physicians, nurses, or peers? Teach Learn Med. 2017; 29(3): 24754. Doi: 10.1080/10401334.2016.1274262.

7. Clarke AJ, Burgess A, Menezes A, Mellis C. Senior students' experience as tutors of their junior peers in the hospital setting. BMC Res Notes. 2015; 8(1): 743. Doi:10.1186/s13104-015-1729-0.

8. Khalid H, Shahid S, Punjabi N, Sahdev N. An integrated 2-year clinical skills peer tutoring scheme in a UK-based medical school: perceptions of tutees and peer tutors. Adv Med Educ Pract.2018; 9: 423-32. Doi: 10.2147/AMEP.S159502.

9. Sarwar S, Tarique S. Peer-Assisted Learning: Who Should Be the Tutor, Fellow Student or Senior Resident. JCPSP. 2016; 26(7): 573-76. PMID: 27504547.

10. Usman R, Jamil B, Waheed N, Ali L, Ali S, Orakzai N, et al. Comparison between facilitator and peer assisted 
learning: an interventional study at Peshawar Medical College. JPMA. 2019; 69(11): 1588-90. Doi: 10.5455/JPMA.286712.

11. Shah I, Mahboob U, Shah S. Effectiveness of horizontal peer-assisted learning in physical examination performance. JAMC. 2017; 29(4): 55965. PMID: 29330977.

12. Ju H, Choi I, Yoon BY. Do medical students generate sound arguments during small group discussions in problem-based learning? an analysis of preclinical medical students' argumentation according to a framework of hypothetico-deductive reasoning. Korean J Med Educ. 2017; 29(2): 101-09. Doi: 10.3946/kjme.2017.57.

13. Van der Hoeven D, van der Hoeven R, Zhu L, Busaidy $\mathrm{K}$, Quock RL. Integration of basic and clinical sciences: faculty perspectives at a US dental school. J Dent Educ. 2018; 82(4): 349-55. Doi: 10.21815/JDE.018.038.

14. Bugaj T, Blohm M, Schmid C, KoehI N, Huber J, Huhn $D$, et al. Peer-assisted learning (PAL): skills lab tutors' experiences and motivation. BMC Med Educ. 2019; 19(1): 353. Doi: 10.1186/s12909-019-1760-2.

15. Khalid H, Shahid S, Punjabi N, Sahdev N. An integrated 2-year clinical skills peer tutoring scheme in a UK-based medical school: perceptions of tutees and peer tutors. Adv Med Educ Pract. 2018; 9: 42332. Doi: 10.2147/AMEP.S159502.
16. Ferreira JJ, Maguta L, Chissaca AB, Jussa IF, Abudo SS. Cohort study to evaluate the assimilation and retention of knowledge after theoretical test in undergraduate health science. Porto Biomed J. 2016; 1(5): 181-5.

17. Alvarez S, Schultz JH. Professional and personal competency development in near-peer tutors of gross anatomy: A longitudinal mixed-methods study. Anat Sci Educ. 2019; 12(2):129-37.

18. Agius A, Stabile I. Undergraduate peer assisted learning tutors' performance in summative anatomy examinations: a pilot study. IJME. 2018; 9: 93.

19. Burgess A, McGregor D. Peer teacher training for health professional students: a systematic review of formal programs. BMC Med Educ. 2018; 18(1): 263. Doi: 10.1186/s12909-018-1356-2.

20. Nshimiyimana A, Cartledge PT. Peer-teaching at the University of Rwanda-a qualitative study based on self-determination theory. BMC Medical Educ. 2020; 20(1): 230. Doi: 10.1186/s12909-020-02142-0.

21. Donohoe CL, Conneely JB, Zilbert N, Hennessy M, Schofield S, Reynolds JV. Docemur docemus: peerassisted learning improves the knowledge gain of tutors in the highest quartile of achievement but not those in the lowest quartile. J Surg Educ. 2015; 72(6): 1139-44. Doi: 10.1016/j.jsurg.2015.07.001.

22. Ningrum R. Students' perception of peer tutor roles in the small group discussion. MS\&E. 2018; 434(1): 012343. Doi:10.1088/1757-899X/434/1/012343. 